\title{
Research
}

\section{Viable Reserve Networks Arise From Individual Landholder Responses To Conservation Incentives}

\author{
Kenneth M. Chomitz ${ }^{1}, \underline{G u s t a v o ~ A . ~ B . ~ d a ~ F o n s e c a ~}^{2}$, Keith Alger $^{2}$, David M. Stoms $^{3}, \underline{\text { Miroslav Honzák }}^{2}$, \\ $\underline{\text { Elena Charlotte Landau }}^{4}$, Timothy S. Thomas ${ }^{1}, \underline{W}^{\text {. Wayt Thomas }}{ }^{5}$, and Frank Davis ${ }^{3}$
}

\begin{abstract}
Conservation in densely settled biodiversity hotspots often requires setting up reserve networks that maintain sufficient contiguous habitat to support viable species populations. Because it is difficult to secure landholder compliance with a tightly constrained reserve network design, attention has shifted to voluntary incentive mechanisms, such as purchase of conservation easements by reverse auction or through a fixed-price offer. These mechanisms carry potential advantages of transparency, simplicity, and low cost. However, uncoordinated individual response to these incentives has been assumed incompatible with the conservation goal of viability, which depends on contiguous habitat and biodiversity representation. We model such incentives for southern Bahia in the Brazilian Atlantic Forest, one of the biologically richest and most threatened global biodiversity hotspots. Here, forest cover is spatially autocorrelated and associated with depressed land values, a situation that may be characteristic of longsettled areas with forests fragmented by agriculture. We find that in this situation, a voluntary incentive system can yield a reserve network characterized by large, viable patches of contiguous forest, and representation of subregions with distinct vegetation types and biotic assemblages, without explicit planning for those outcomes.
\end{abstract}

Key Words: Bahia; biodiversity; conservation; conservation planning; economic instruments; land use.

\section{INTRODUCTION}

Drastic anthropogenic loss of habitat in biologically outstanding regions has created biodiversity hotspots (Myers et al. 2000, Cincotta et al. 2000) in which the long-term viability of threatened endemic species is questionable in the absence of conservation intervention. Conservation of these threatened ecosystems requires implementation of landscape-scale networks that restore (Rosenzweig 2003) and maintain sufficient contiguous habitat to support viable species populations and ecological processes (Sanderson and Harris 2000, Sanderson et al. 2003). In general, and especially in the densely settled hotspots, this goal will require the cooperation of landholders. This will usually entail landholders' acceptance of some restrictions on land use or land management. Here we explore the potential to use economic instruments to induce voluntary acceptance of these restrictions. We use as an example a segment of the Atlantic Forest of Brazil, a highly fragmented ecosystem of global biodiversity significance, which has been the focus of efforts at landscape level conservation and corridor construction.

The conservation literature has devoted extensive attention and sophistication to the problem of where to impose land use restrictions. (See reviews in Margules and Pressey 2000, Stoms et al. 2004, Brooks et al. 2006.) The problem is framed in optimization terms, for instance, selecting a set of reserve sites that achieves specified environmental goals at minimum cost. Many of the earlier exercises focused narrowly on species representation as a goal, and used crude proxies for cost, such as area. More recently, the set of objectives has expanded to include the resilience or persistence of protected biodiversity, and the maintenance of ecological processes (Cowling et al. 2003). Economic measures of opportunity cost, rather than land area, are increasingly used as a minimand. Detailed conservation plans have been developed for regions including Papua New Guinea (Faith et al. 2001) and 
the Cape Provinces (Cowling et al. 2003). An underlying premise is that explicit central planning is necessary to achieve landscape-level objectives such as connectivity and representation. The result, typically, is a rather tightly constrained plan that specifies precisely which landscape units are to be included in the conservation system.

However, according to Faith et al. (2003) "In spite of a decade or more of work on reserve selection methods, no complete set of areas produced by such computer algorithms, to our knowledge, has been implemented anywhere in real-world regional biodiversity planning." Like Faith et al. (2003), we believe that this is because the optimization approach, though useful for motivating data collection, assessing options, and providing a solid basis for discussion of issues may not always frame the problem in a politically realistic way. It has three shortcomings. First, from a political view, the problem is usually not one of minimizing the cost of achieving a set of precisely defined objectives. Instead, it is determining what kinds of environmental benefits can be achieved with available funds and given constraints on implementation. Second, the optimization approach usually embodies, in its goals, debatable assumptions about trade-offs between different environmental benefits, or between costs and benefits. If the goal is, for instance, to ensure the representation of each of $\mathrm{n}$ species in two sites, then there is no benefit to adding a third site for some species, and implicitly an infinite cost to the failure to achieve a second site. In the political sphere, people will debate these costs and benefits with different preferences in the matter. Third, and most crucially, the optimization approach focuses on where to intervene, not on how to induce landholders to comply with the plan. The result is a plan that is, in theory, efficient in achieving the specified goal, but in practice may not be implementable because it relies on compulsion, which is politically costly, or on nearly universal cooperation of designated landholders, which may not be forthcoming.

In this paper we frame the problem differently, approaching it from the viewpoint of implementability and political acceptability rather than theoretical cost-efficiency. We specify a set of environmental criteria or dimensions on which to assess landscape outcomes, including representation, viability, i.e., a function of connectivity or contiguity, and resilience of biodiversity elements. We assume that higher values along each of these dimensions are preferred, but do not presume to specify trade-offs between the dimensions. We describe a class of conservation programs, i.e., voluntary responses to incentive offers, which are arguably attractive at the individual and societal level. The choice of program rules and expenditure determines individual landholder responses, which in turn shape the resulting landscape configuration. That outcome can be assessed by conservation scientists, policymakers, and civil society. The question we address is not whether the resultant scores on the environmental criteria are achieved at theoretical least cost. They will not be. Rather, we pose the question of whether uncoordinated individual participation decisions can possibly yield desirable landscape-level features such as representation and viability. These features do in fact emerge in a simulation of an incentive-based voluntary program for southern Bahia, Brazil, an important biodiversity hotspot. This result stems from a correlation between low market value and remaining forest cover that may be typical of agricultural landscapes in fragmented biodiversity hotspots.

\section{Methods of securing landholder compliance with conservation plans}

Before proceeding to a description of the simulation model, we examine the implementation drawbacks of tightly prescriptive conservation plans, and why voluntary programs may be able to overcome them.

Tightly prescriptive conservation plans must secure the cooperation of particular landholders in order to meet goals such as connectivity. There are three approaches: exhortation, compulsion, and compensation. In the first approach, technical criteria are used to identify areas more or less suitable for different uses, and landholders are exhorted to hew to the recommended use. This can work when the plan provides relevant new information, or when tight informal social controls enforce a consensus that the plan supports a collective goal. In general, however, when privately profitable uses diverge from recommended ones, exhortation is insufficient to change behavior.

The second approach, typified by prescriptive zoning plans, uses the threat of legal penalties to enforce compliance with the land use plan. The success of top-down imposition of zoning might be expected to depend on the depth of society's interest 
and the strength of its institutions. We might expect weak implementation, or lack of compliance, when macro-scale zoning plans impose substantial ex post costs on politically powerful interest groups such as landholders or loggers. This has been the fate to date of two prominent statewide zoning exercises in the Brazilian Amazon (Mahar 2000, World Bank 2003). Indonesia's forest zoning plan has also been widely flouted (FWI/GFW 2002).

In the third case, the government can pay for landholder compliance. If the landholder is not obliged to accept an offer, then owners of properties who are aware that they occupy crucial locations in the reserve network, for instance, corridors between two large habitat blocs may exploit their quasimonopoly situation to demand high payments. Alternatively, the government may be able to exercise the power of eminent domain, i.e., compel the landowner to sell. This approach is sometimes used in setting up protected areas. However, regulatory proceedings to determine fair compensation can be contentious and incur substantial overhead costs, because landholders are better informed than the purchasing authority about their lands' value (Innes et al. 1998, Stoneham et al. 2003). When very large areas are at stake, it could be problematic to implement technocratically designed programs for compensating groups of landholders. Such programs could be perceived as prone to corruption or political manipulation.

A promising emerging alternative to top-down planning is to use participatory mechanisms to allow stakeholders to negotiate land allocations and uses. These have often been applied to relatively small areas. However, Australian states use informationintensive consultative processes to create Regional Forest Agreements that specify statewide zones for timber exploitation and conservation (Hoare 2006).

This paper describes another approach to reserve system implementation. It starts not with a unique, prescribed configuration, but rather a set of incentive offers to a set of eligible landholders (Ferraro 2000, Ferraro and Kiss 2002, Faith et al. 2003). Eligibility might be defined through a participatory zoning process. Rather than negotiate with individual landholders, these programs offer fixed payments, or solicit auction bids, for the delivery of conservation services such as native forest protection, reforestation, and restoration of riparian vegetation (Salzman et al. 2001). Eligible landowners voluntarily decide whether to apply for participation, and the resultant conservation network emerges as a consequence of many independent choices about participation. Examples includes the US Conservation Reserve Program (CRP), the Victoria, Australia BushTender program (Stoneham et al. 2003), and the Costa Rica Environmental Services Payment program (Chomitz et al. 1999). Because they depend on voluntary responses to a rule-driven set of incentives, generating competition among landholders, such programs potentially combine transparency, simplicity, low institutional overhead, and low budgetary cost compared to a predesigned, imposed reserve network design. Indeed, we posit that programs will be more politically acceptable, the simpler are the rules, the broader the eligible set of participants, and the more transparent and streamlined the procedure for prioritizing properties and disbursing funds.

It is not at all obvious, however, that a voluntary approach, based on uncoordinated individual actions, can satisfy the landscape-level connectivity and representation requirements of a biodiversity reserve network. Of course, hybrid systems are possible, when zoning is used to define regions in which landholders can participate in auction-like systems. Examples include tradable development rights programs in some United States counties (Johnston and Madison 1997). However, there is a tradeoff: as the zoning is more tightly constrained, representation and connectivity are theoretically easier to achieve, but landholder compliance may be more difficult to secure, for the reasons we have described. In this paper we explore the properties of a voluntary system unconstrained by zoning.

\section{MATERIALS AND METHODS}

\section{Study area}

We simulated the conservation impact of a hypothetical voluntary program, similar to CRP or BushTender, on a $7.46 \times 10^{6}$ ha section of the southern coast of Bahia, Brazil. The study area constitutes an important center of endemism within the larger remaining Atlantic Forest, a biodiversity hotspot that harbors as endemics more than $2 \%$ of the world's vascular plants and vertebrates (Myers et al. 2000) and is often considered one of the world's highest conservation priorities (GalindoLeal and Gusmão Câmara 2003). Anthropogenic pressures have reduced the Bahian forest to $5 \%$ or less of its original area (Thomas et al. 1998, Saatchi et al. 2001). 


\section{Geographic data and assumptions}

Since we lacked data on actual property boundaries, we gridded the landscape into 98 ha land units assumed to represent properties. The unit size, chosen to accommodate an integral number of landcover pixels, represented a compromise between the desirability of representing very fine-scale decisions about land use versus the computational and data burden of representing a large number of units. According to the Agricultural Census of 1996, $73.3 \%$ of privately owned forest area in South Bahia was located in agricultural establishments of 100 ha or more. A slightly smaller proportion of all agricultural areas were encompassed by these establishments. An additional 11.3\% was found in establishments between 50 and 100 ha. Hence in our view the decision unit size provides a reasonable approximation to a scale that might be affected by policy. The use of gridded land units for illustrating issues in conservation science is well established in the broader literature.

To assess the conservation and economic impact of alternative policies, we assembled the following geographic data for each unit:

\section{Land cover}

We used a land cover classification (Landau et al. 2003) based on 30-m resolution Landsat data for 1996-1997 (Fig. 1). The classification distinguishes anthropogenic categories including capoeira, i.e., forest in initial stages of regeneration from cleared land or logged forests, no continuous canopy yet formed; cocoa plantations including cabruca, a form of shade cocoa in which the native forest overstory is retained; eucalyptus plantations, pasture and other agriculture, and bare fields. Mature forest encompasses intact primary forest and regenerated secondary forest, which has reached full height and has a closed canopy; it is distinguished from restinga natural open vegetation, and caatinga, dry forest, at the edge of the study area.

\section{Land value}

A land value surface was computed by Chomitz et al. (2005). They conducted a survey of land sales transactions. Within randomly selected municipios, the equivalent of counties, a survey team gathered information on 231 rural property sales, including the actual sales prices and the characteristics and precise locations of the properties. The locations were then georeferenced to detailed map data on soil agronomic suitability, slope, climate, and location relative to roads. Since these factors would be expected to influence the profitability of farming, Chomitz et al. adapted Mendelsohn et al. (1994) in regressing the per-ha sales price on land characteristics, including land cover. Consistent with theory, sales price was strongly positively related to soil quality, strongly negatively related to slope, and negatively related to distance to road. Holding these factors constant, forest cover was associated with a $70 \%$ reduction in market price. The presence of forest cover in this long-settled region may be a marker for poor agronomic qualities not captured by the soil quality indicator. Or its low value may reflect the operation, albeit imperfect, of regulations that restrict deforestation, and hence reduce options for land use, including a law that requires landholders to maintain $20 \%$ of each property as a forest reserve.

The regression parameters were then applied to the maps of explanatory variables, generating an imputed value surface. The calibrating equation had an adjusted $R^{2}$ of 0.274 , indicating that reported land values included some measurement error and the effects of some unobserved variables. Hence the imputed land value surface is smoother than the unobtainable, actual land value surface.

\section{Bioregions}

Thomas and Barbosa, (in press) and Veloso (1992) classified the vegetation of southern Bahia and provided the criteria for delimiting distinct floral and faunal assemblages. Using these criteria, the region was divided into eastern and western portions, i.e., areas with primarily moist tropical forest were separated from those with mostly semideciduous forest. Eastern Bahia is home to many species with restricted distributions (Thomas et al. 1998). Large rivers running west to east mark geological changes, which are expressed as distinct soils, forest types, and biota (Gouvêa et al. 1976) and may directly function as barriers to vertebrate species migration (Prado et al. 2003). Thus, seven bioregions (Fig. 2) were established with distinct vegetation types and biotic assemblages. An additional bioregion, the coastal/riverine/wetland region, was not included in the study because its conservation requirements are different. 
Fig. 1. Land cover.

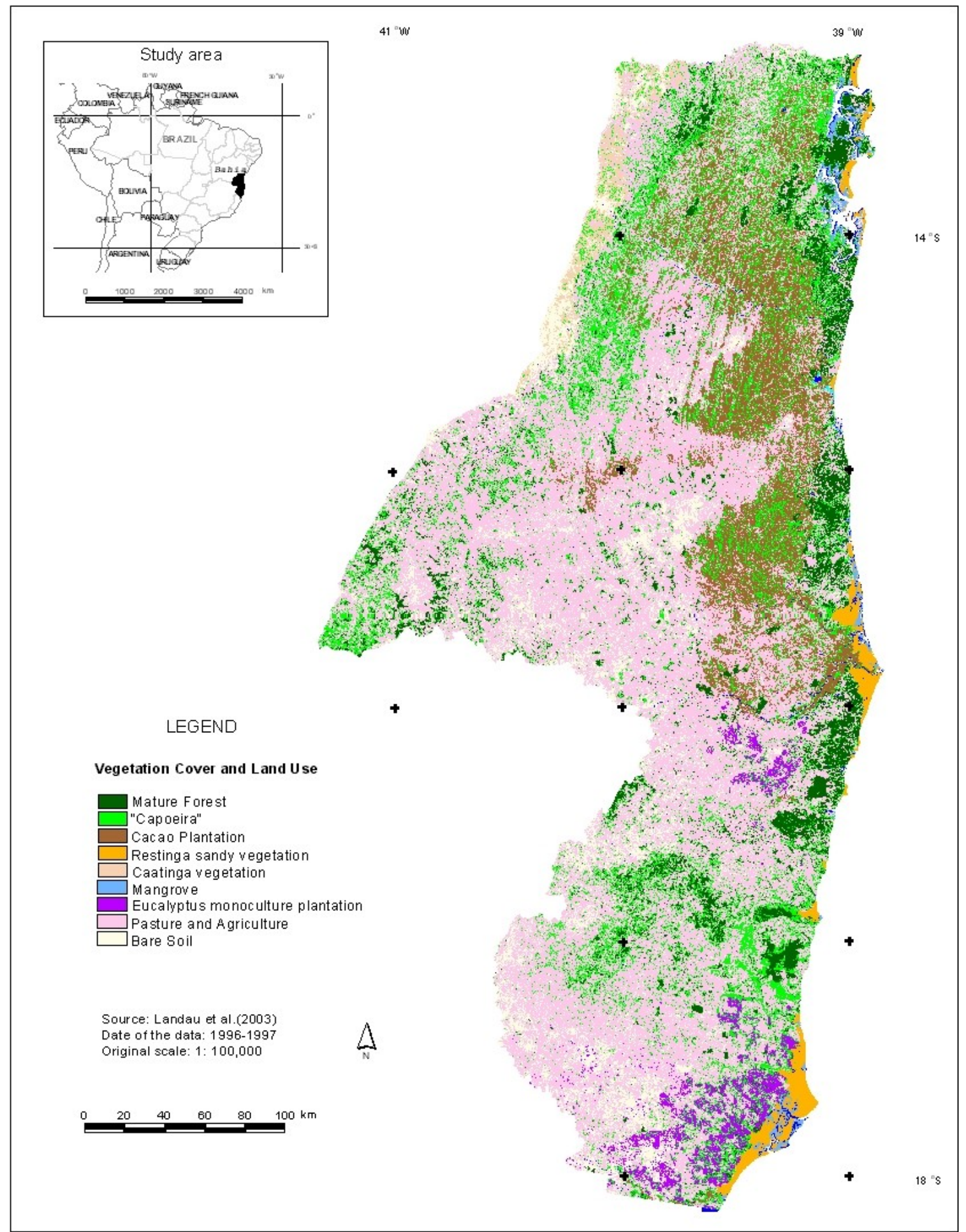


Fig. 2. Bioregions.

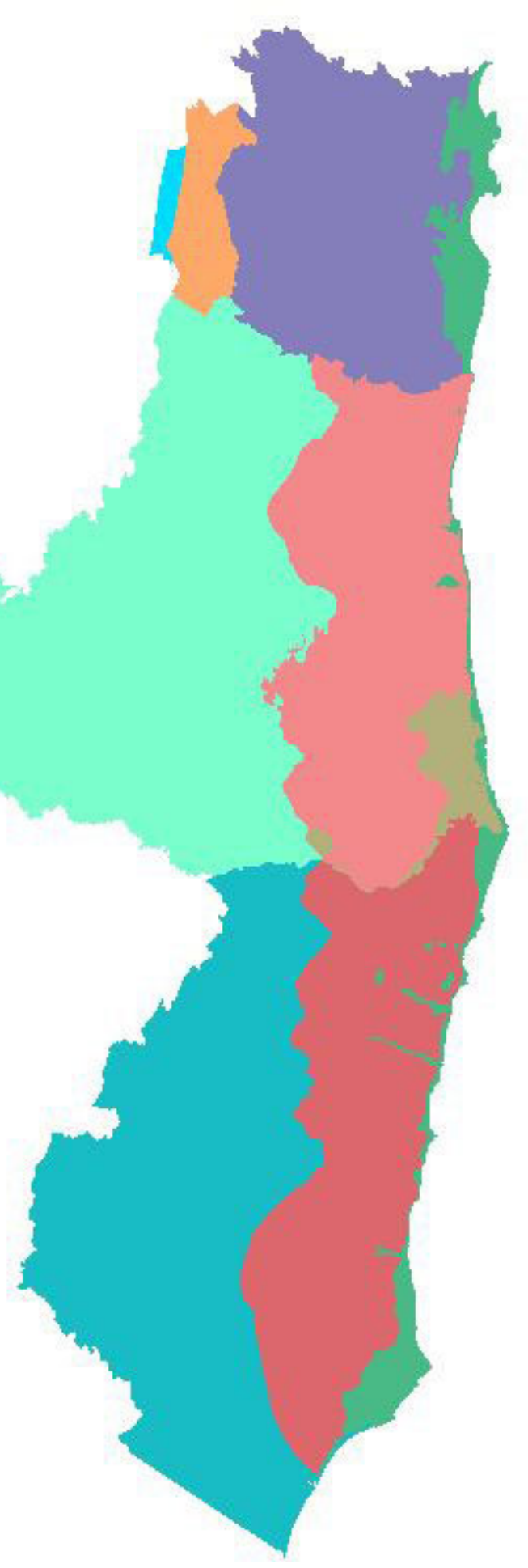

\section{Bioregions}

Central Lowand Forest

Central Semi-deciduous Forest

Central Tabuleiro Forest

Coast/Wetland/Riverine

Northern Caatinga

Northern Lowland Forest

Northern Semi-deciduous Forest

Southern Semi-deciduous Forest Southern Tabuleiro Forest 


\section{Policy simulation}

In our hypothetical policy, a government agency with a fixed budget conducts a reverse auction. All landholders are assumed to submit bids specifying the extent and quality of forest cover on their property, and the minimum one-time payment necessary to induce them to put the property under a permanent conservation easement.

The supposition of a one-time payment is made for convenience of exposition. A one-time payment would be effective only in the presence of reliable institutions for enforcement of a permanent commitment. Alternatively, the agency could offer an annual stream of payments with the same net present value as the one-time payment. For instance, instead of making a one-time payment of $\$ \mathrm{x}$, the agency could make an annual payment of $\$ r x$, where $\mathrm{r}$ is the real, inflation-adjusted interest rate. In recent years the Brazilian treasury has offered investors bonds with inflation-indexed interest rates of roughly $\mathrm{r}=10 \%$. The annual payment would be conditional on complying with the terms of the conservation easement.

We assume, conservatively, that the landholder's bid price is the market value of the land. The bid price may be lower if the proprietor continues to enjoy benefits such as ecotourism revenue, or enhanced value of nearby residential sites. Operationally, the bid price is represented at the land decision unit level in as the aggregate of the pixellevel values from the imputed land value surface. The purchasing agency rates the environmental quality of the bid using an environmental benefit index (EBI), as in the US Conservation Reserve Program or BushTender. We used an EBI based on forest cover quality, awarding more points to mature than to secondary forest, but more complex EBIs could be defined (See the Appendix.) The agency ranks bids using a cost-effectiveness index that divides EBI-weighted area by bid price. Conservation easements are purchased in descending order, at each landholder's bid price until the budget is exhausted. With these assumptions, the budgetary or fiscal cost is the same as the social or opportunity cost of conservation.

Auction systems may however not be fully successful at eliciting landholders' private information about the value of their land, especially if the auction is repeated (Smith 1995). Landholders with low value land or with high personal preferences for conservation may bid strategically, asking for prices above their opportunity cost of farming, thus capturing information rents (Smith and Shogren 2002). Stoneham et al (2003), analyzing actual bid data in a conservation auction, show that bidders are far from capturing all available rents. However, for comparison we evaluated the budgetary outlay under the fixed-price offer system that corresponds to each auction scenario. Under the fixed-price offer system, the purchasing authority offers landholders a fixed payment per EBIweighted ha to put their property under a conservation easement. If this offer is set at the same level as the highest accepted bid per EBI-weighted ha as an auction scenario, it will elicit the same participants as the auction, and would have the same social opportunity cost. However, inframarginal bidders would receive rents equivalent to the difference between their opportunity cost and the offer. Such a scheme is simpler than an auction program, and therefore may be attractive on political grounds even though it involves greater expenditure by the purchasing authority. Costa Rica's Environmental Services Payment program, for instance, uses fixed payments despite the potential efficiency advantages of differentiated payments. The expenditures under this scheme can be viewed also as the expenditures that would result from an auction scheme in which strategic bidders managed to capture all information rents.

The simulation of landholder response and associated land use configurations and payments was performed using the Toolbox of Applied Metrics and Analysis of Regional Incentives (TAMARIN) (Stoms et al. 2004; program is documented at www.tamarinmodel.org and is available on request). This GIS-based software program represents the grid of land decision units that comprises the study area. The underlying database contains information about land values at the 98 ha grid cell level, and about land cover at the 30-m pixel level. Given a definition of the EBI and a budget, TAMARIN simulates the auction system described above, identifying land units that successfully bid for inclusion into the reserve system. Based on prespecified land-cover transition rules for protected and unprotected areas, it depicts a long-term land cover scenario. It then assesses the connectivity, and other ecological characteristics, of the resultant landscape, based on parameters including species gap-crossing distance and habitat requirements. 


\section{Land use change scenarios}

Assessing the impact of the policy requires assumptions about the baseline scenario for land use change. Econometric models of land cover change (e.g., Chomitz and Gray 1996) typically find that deforestation is positively associated with the same factors that contribute to land value: road proximity and soil quality. This might support a scenario in which projected deforestation rates of unprotected land units would be assumed proportional to their land value. Such a scenario might be most plausible when forest is abundant and deforesters prioritize the most attractive plots. However, there are other, equally plausible, hypotheses linking land value and deforestation. For instance, in non-frontier areas one might hypothesize rapid deforestation of all forested plots whose value exceeded a low threshold. The actual relationship can only be assessed empirically.

Unfortunately comprehensive region-wide data is not available to estimate an empirical model. However, recently analyzed data for a portion of our study region (Santos 2005) found a 13\% decrease in forest cover over 1996-2004. Some forest was transformed to relatively high value eucalyptus plantations, but in one municipio with very low value land, there was substantial forest conversion to small-scale pasture and agriculture. In addition, Rolim and Chiarello (2004) report that the oldgrowth forest trees incorporated in the region's extensive cocoa agroforests are nearing the end of their lifetime and are unlikely to be replaced.

For these reasons, we believe that policymakers, motivated by a precautionary principle and facing an uncertain future, might reasonably adopt a pessimistic baseline scenario when considering the long-term survival of an irreplaceable ecosystem. That scenario assumes that, in the absence of protection, all mature forest areas will face continuing pressures from pasture expansion, subsistence agriculture, and timber extraction, gradually degrading over the medium term into secondary vegetation. However, we flag the importance of improved modeling of land use change, as such data becomes available. Differential risks of deforestation could then be incorporated into the definition of the EBI and thus into the prioritization of bids by land units.

For land units enrolled in the conservation program, or are already in protected status, we assume that mature forest is retained, existing agriculture is abandoned in favor of forest regeneration, and both capoeira and agricultural lands are designated as "regenerating forest" which, over time, will develop into closed forest, become more diverse, and ultimately resemble mature forest. Consistent with evidence (Guevara and Laborde 1993, Landau 2001, Martini et al., in press) we assume that unassisted regeneration will proceed naturally within land units that have existing seed sources. (See the Appendix for more detail on assumed land use transitions.)

\section{Evaluation criteria}

Our evaluation criteria differ from those commonly used in conservation planning, because we frame the problem differently. Conservation plans typically define a fixed environmental goal, based on implicit weightings of the relative importance of representation, redundancy, and resilience in the reserve network. The plans then seek to minimize the cost of achieving that specified goal. In our framework, the public choice variables are the size of the budget allocated to the program, and the prioritization rules. The resulting landscapes were evaluated on four principal conservation criteria defined at greater length below: viability, representation, and redundancy of surviving forest fragments, and the proportion of surviving forest free of edge effects. The literature does not give clear guidance on the relative importance of these criteria (Stoms et al. 2004), and so we do not aggregate them into a one-dimensional index.

Forest fragments are defined as contiguous assemblages of mature or regenerating forest, allowing for gaps of up to $500 \mathrm{~m}$ for pasture, crops, and bare land, or $1000 \mathrm{~m}$ of secondary forest or shaded cocoa, i.e., cocoa grown under shade trees. A fragment is deemed viable if it is at least 10,000 ha in extent, based on simulations (Paglia 2003) of extinction probabilities for Cebus xanthosternos, a large endemic primate that is one of the most areademanding endemic species of southern Bahia. Viability is thus a function of connectivity and contiguity. "Representation" is gauged by the number of distinct bioregions that exhibit viable fragments. "Redundancy" is measured by the number of viable fragments within a bioregion. "Edge forest" is defined as that within $300 \mathrm{~m}$ of agriculture other than shaded cocoa or plantations. For the purposes of this study, we excluded the coastal and semiarid bioregions because their 
conservation considerations and anthropogenic pressure differ considerably from those of humid forests not adjacent to the coast.

\section{RESULTS}

In the absence of any intervention, future forest area persists and regenerates only within the current protected areas and is predicted to be 85,000 ha. Of this, $73 \%$ is within fragments deemed viable, i.e., greater than 10,000 ha in extent (Fig. 3). For a hypothetical budget of $\mathrm{R} \$ 20 \times 10^{6}$, at the time of the land value study, i.e., approximately US\$1= $\mathrm{R} \$ 1.80$, future forest area more than doubles to reach 175,000 ha, of which the proportion in viable fragments is about $50 \%$. Rising budgets induce the expansion and coalescence of large fragments more rapidly than enrollment of unconnected small ones (See Figs. 4 and 5). Consequently, the proportion in viable fragments increases to $63.4 \%$ at $\mathrm{R} \$ 80 \times 10^{6}$. Thereafter, as budgets increase to $\mathrm{R} \$ 200 \times 10^{6}$, the proportion stays between $59 \%$ and $62 \%$. The proportion of total budget going to these larger fragments rises to $56 \%$ at $\mathrm{R} \$ 80 \times 10^{6}$ and then declines to $51 \%$.

These large fragments are of relatively high habitat quality. The proportion of edge forest in these fragments increases from $13.4 \%$ at $\mathrm{R} \$ 20 \times 10^{6}$ to $22.6 \%$ at $\mathrm{R} \$ 80 \times 10^{6}$, holding approximately constant at higher budgets. Nonedge mature forest declines gradually from $62.7 \%$ at $\mathrm{R} \$ 20 \times 10^{6}$ to $54.5 \%$ at \$R200 X $10^{6}$.

Small fragments, of less than 200 ha, increase as a proportion of total surviving forest area from $6.1 \%$ at $\mathrm{R} \$ 20 \times 10^{6}$ to $7.8 \%$ at $\mathrm{R} \$ 60 \times 10^{6}$, holding approximately constant at higher budget levels. These fragments are much more subject to edge effects than larger fragments. As budgets increase, the total area of these fragments increases from about 11000 to 49000 has, but the portion of these fragments in non-edge mature forest declines from $46.4 \%$ to $12.6 \%$. However, they account for a relatively small proportion of the budget, ranging from $13.4 \%$ to $9.9 \%$ of the total.

Overall representation and redundancy increase with budgets up to a point (Table 1). In the baseline, business-as-usual scenario, existing protected areas contain four viable fragments in two of the seven bioregions. At $\mathrm{R} \$ 80 \times 10^{6}$, coverage increases to eleven viable fragments in four bioregions. At $\mathrm{R} \$ 160 \times 10^{6}, 14$ viable fragments in 5 bioregions are secured.

The number of viable fragments in a bioregion is related to the initial extent of mature forest (Table 1). Holding budget constant, the number of viable fragments tends to increase as the initial mature forest area increases. The exception is the central semideciduous zone, which contains about 80,000 ha of mature forest. This forest is highly fragmented, scattered over a relatively large area, and has relatively high bid prices due to the lower average level of forest cover. This bioregion does not acquire a viable fragment even in the highest budget scenario, when $44 \%$ of its original mature forest is placed under protection. Viable fragments can however be induced here, by earmarking budget specifically for this region. However, a dedicated regional budget of $\mathrm{R} \$ 64 \times 10^{6}$ is required to achieve the first viable fragment, because a large proportion of expenditure is devoted to unconnected, subviable fragments. This suggests that the simple incentive system simulated here may not work very efficiently in the most extreme cases of fragmentation. Hybrid approaches, blending voluntarism and zoning, may be necessary there.

For each auction scenario, we calculate also the equivalent budgetary outlay for the equivalent fixed-price offer scheme. Under this kind of program, the budgetary outlay is $30 \%$ to $90 \%$ higher than in the corresponding auction scheme; the percentage increases with program size. In the $\mathrm{R} \$ 80$ $\mathrm{X} 10^{6}$ scenario, for instance, the one-time fixed offer is $\$ 188 /$ ha for unprotected areas. This may be compared with the \$353/ha annual payments under China's "Grain for Green" cropland retirement program (Uchida et al. 2005) or the $\$ 42 /$ ha annual payments under the Costa Rican Environmental Services Program.

\section{DISCUSSION}

In principle, optimization techniques can be used to design a biodiversity reserve network that minimizes the social cost associated with a set of ecological goals such as connectivity, representation, and low ratios of edge to interior forest. These techniques may be particularly valuable in identifying irreplaceable areas of high biodiversity value for inclusion in a network. However, it may 
Fig. 3. Extent of conserved forest fragments by fragment size class and budget scenario.

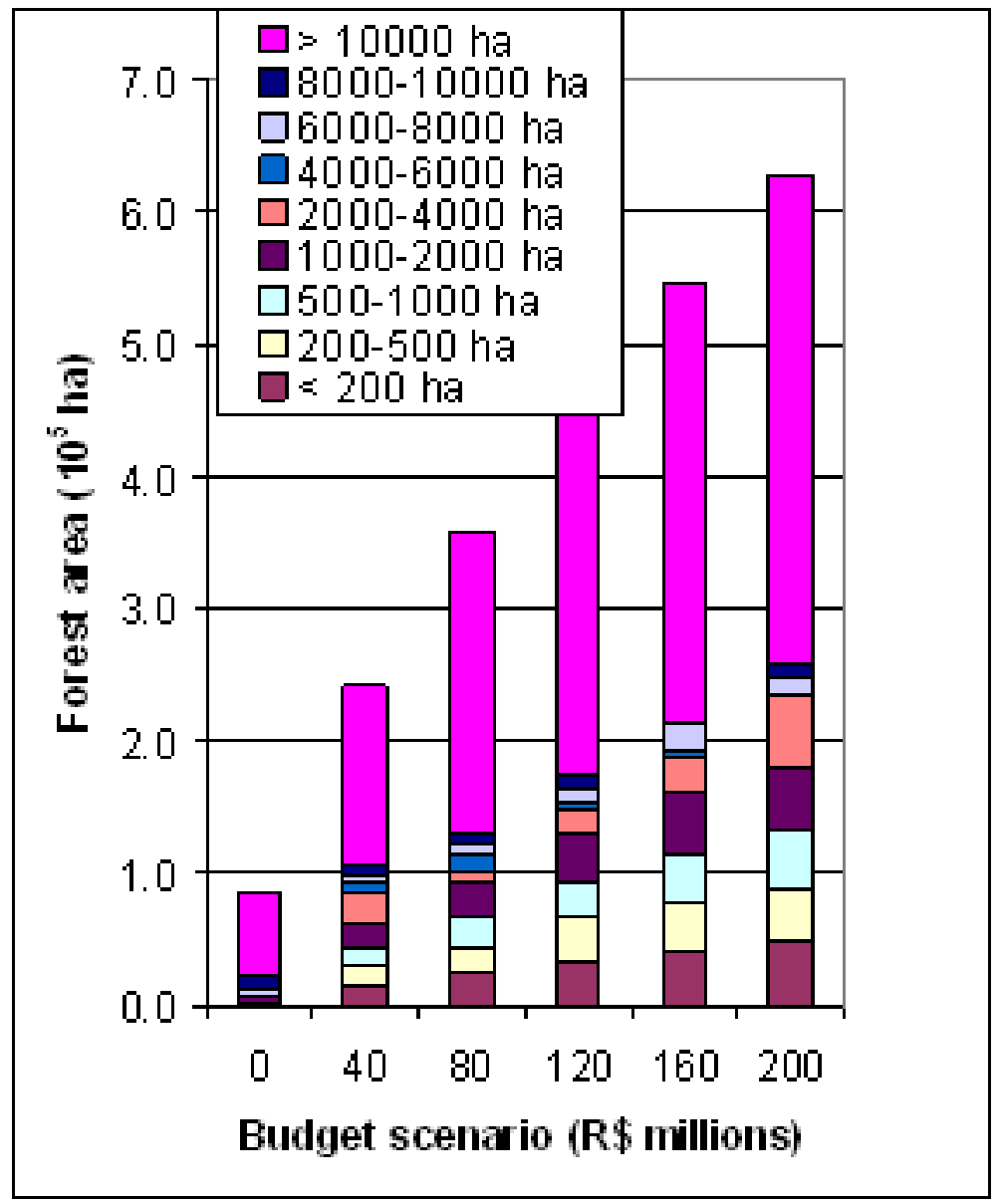

be both difficult and unnecessary to impose a tightly constrained reserve network plan on a landscape of unwilling landholders.

Voluntary incentive programs offer potentially greater political acceptability but do not automatically guarantee representation or viability within the resultant reserve network. However, our results suggest that a voluntary incentive program, with simple, property-specific enrollment criteria, could generate a landscape-level biodiversity reserve network that represents a significant range of the Bahia Atlantic Forest's biodiversity with resilience and redundancy. It does so, furthermore, at relatively low social cost and with relatively high environmental efficiency - for instance, with about $90 \%$ of the funds devoted to patches of greater than
200 ha, which are likely to be more persistent and less subject to edge effects than smaller patches. Connectivity among existing and regenerated forest fragments arises without central planning or costly and time-consuming negotiation with individual landholders. As has been demonstrated with random binary maps (Gardner et al. 1987), connectivity is achieved when the proportion of enrolled habitat exceeds a landscape-specific threshold. In our simulation, higher payment offers increase the local proportion of planning units under conservation, thus breaching local thresholds for connectivity.

The results for southern Bahia are the consequence of a strong inverse correlation between forest cover and land value, and spatial autocorrelation of both these variables. These correlations may arise as the 
Fig. 4. Map of conserved forest fragments in $\mathrm{R} \$ 0$ and $\mathrm{R} \$ 80 \times 10^{6}$ budget scenarios.

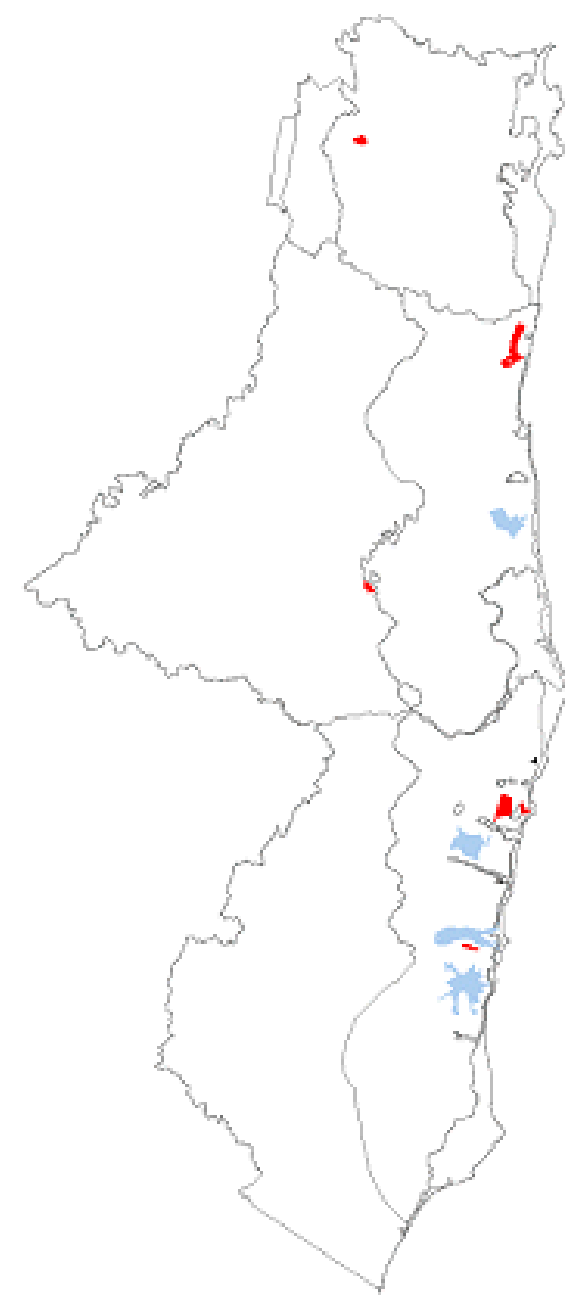

Baseline scenario

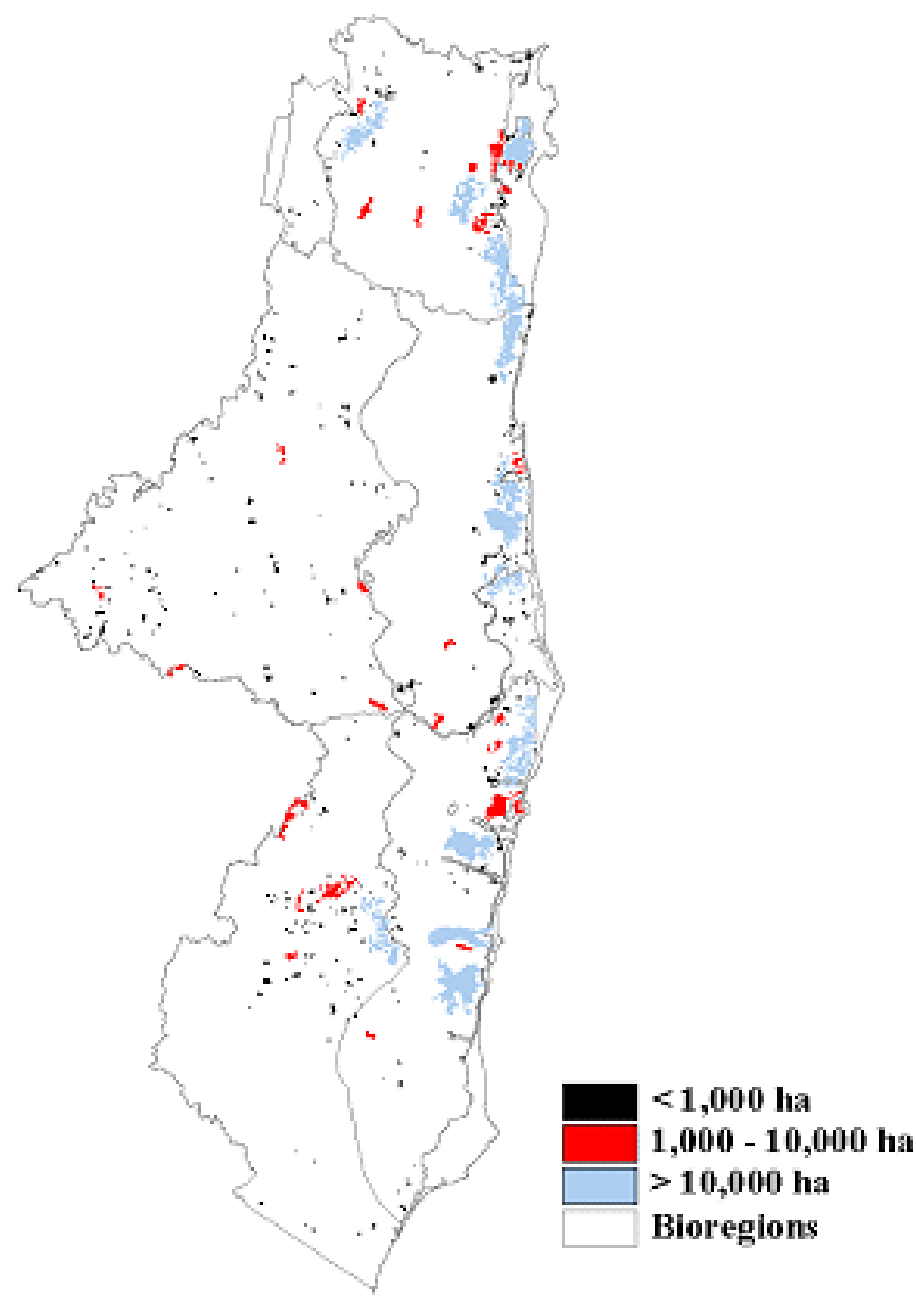

$\mathrm{R} \$ 80$ million scenario joint consequence of typical biophysical landscape features, e.g., patchiness of soil types and slopes, and typical economic processes of deforestation, e. g., preferential deforestation of more accessible, better quality land. They may also result from partial enforcement of regulations against deforestation. Both of these features may generalize to other hotspot areas in which severe habitat fragmentation has prompted consideration of reserve network construction. For instance, Brandon et al. (2005), in a priority-setting exercise for Mexico, identify 94 ,
0.25 degree grid cells with very low agricultural value, which together contain all vertebrate species not present in current protected areas. More than half these cells have a population greater than 10,000 , and more than a quarter have a population greater than 50,000, suggestive of settlementrelated habitat fragmentation. A global inventory of "imminent extinction spots," i.e., small areas with endemic threatened species (Ricketts et al. 2005), includes southern Bahia along with many areas with fragmented habitats, including Madagascar, 
Fig. 5. Animation: expansion of viable reserves with increasing budgets.

Click here or go to http://www.ecologyandsociety.org/voll1/iss2/art40/figure5.html to view animation

Mexico, and the western Ghats. However, the generality of the proposition made here remains to be confirmed through more rigorous studies.

The approach outlined here will not be universally applicable, and it will generally need to be complemented by other tools. It will be inappropriate when conservation considerations leave little room for flexibility, e.g., for maintenance of areas with irreplaceable biodiversity, or with nonsubstitutable environmental functions such as riverine forest. It will fail to generate contiguous areas when forest cover is spatially autocorrelated but land value is not, or when forest cover is extremely sparse. In addition, it depends on the existence of relatively secure land tenure.

We did not compare the efficiency of our simulations to an "optimal" reserve network because we do not think the latter is implementable. However, it is fair to ask whether auction-type programs are themselves affordable, acceptable, and implementable. With regard to affordability, the conservative assumptions used here may greatly overstate the actual opportunity cost of the program, especially if ecotourism and other non-exploitative land uses are developed. We have not however, accounted for recurrent costs of monitoring and enforcement of the conservation agreements. The social acceptability of the program depends on the incidence of costs and benefits. Because forestland is disproportionately held by large landholders in Bahia, payment recipients under the hypothetical scheme would probably tend to be comparatively wealthy. To ensure social acceptability of the program it might be important to ensure that the financing burden did not fall disproportionately on poor people. For instance, the program could be financed via a tax on other wealthy landholders, $i$. e., those out of compliance with the legal forest reserve obligation (see Chomitz 2004) or through national or international payments for ecosystem services. The program incorporates low-value land and, thus, would not tend to frustrate aspirations of landless people to obtain good farmland through land reform. Finally, implementation of such a program would require a sophisticated institution for paying and contracting with landholders and monitoring and enforcing the easement contracts. Recently established programs in Costa Rica and Mexico provide potential models for study in the developing world.

An area for further research is the potential for increasing the program's efficiency through finetuning of the eligibility, payment, and prioritization rules. For instance, zoning could be used to restrict eligibility to areas of known endemism, or to exclude areas in which forest cover is so low that connectivity is difficult. The environmental benefit index could be modified to include a measure of the complementarity of a plot's biodiversity to that in the existing reserve system, following Faith et al. (2003), or the potential for connectivity, based on proximity to forests on other properties. To increase connectivity, the payment scheme could be modified to include the "agglomeration bonus" suggested by Parkhurst et al. (2002), in which landholders receive a premium if their neighbors also enroll. Separate budgets could be allocated for each bioregion. All these approaches potentially incur political costs because of their increased complexity or because they are seen a priori to favor certain geographical regions; these potential drawbacks have to be balanced against the possibility of increased cost-effectiveness.

Hotspots hold much of the irreplaceable global biodiversity, in addition to being highly threatened (Rodrigues et al. 2004). The results of our study point to a promising way to implement incentive agreements with potentially far reaching biodiversity conservation benefits. Existing and proposed funding mechanisms to address the Millennium Development Goal for environmental sustainability, calling for significant reduction in current rates of biodiversity loss by 2010, could, given adequate institutional arrangements, use these types of approaches to achieve more efficient results in biodiversity hotspots located in developing countries. 
Table 1. Viable reserves by budget scenario and bioregion.

\begin{tabular}{|c|c|c|c|c|c|c|}
\hline \multirow[t]{2}{*}{ Bioregion } & \multirow{2}{*}{$\begin{array}{c}\text { Initial } \\
\text { mature forest } \\
\text { area }\end{array}$} & \multirow{2}{*}{$\begin{array}{l}\text { Initial ratio, } \\
\text { mature forest/ } \\
\text { total area }\end{array}$} & \multicolumn{4}{|c|}{$\begin{array}{l}\text { Viable fragments by scenario } \\
(\mathbf{R} \$ \mathbf{1 0})\end{array}$} \\
\hline & & & $\mathrm{R} \$ 0$ & $\mathrm{R} \$ 80$ & $\mathrm{R} \$ 160$ & $\mathrm{R} \$ 200$ \\
\hline $\begin{array}{l}\text { Northern Semideciduous Forest } \\
\text { (NSF) }\end{array}$ & 4107 & $2.7 \%$ & 0 & 0 & 0 & 0 \\
\hline Central Tabuleiro Forest (CTF) & 18662 & $16.0 \%$ & 0 & 0 & 1 & 1 \\
\hline $\begin{array}{l}\text { Southern Semideciduous Forest } \\
\text { (SSF) }\end{array}$ & 72336 & $4.6 \%$ & 0 & 1 & 2 & 2 \\
\hline Central Semideciduous Forest (CSF) & 78469 & $3.8 \%$ & 0 & 0 & 0 & 0 \\
\hline Central Lowland Forest (CLF) & 82486 & $7.7 \%$ & 1 & 2 & 2 & 2 \\
\hline Northern Lowland Forest (NLF) & 100294 & $10.8 \%$ & 0 & 4 & 4 & 4 \\
\hline Southern Tabuleiro Forest (STF) & 145656 & $13.3 \%$ & 3 & 4 & 5 & 4 \\
\hline
\end{tabular}

Responses to this article can be read online at: http://www.ecologyandsociety.org/voll1/iss2/art40/responses/

\section{Acknowledgments:}

Support for this research was provided by the World Bank's Research Support Board and Development Research Group, the Center for Applied Biodiversity Science at Conservation International, The Moore Family Foundation, The Gordon and Betty Moore Foundation, PROBIO, the National Science Foundation, and the Pilot Program for the Brazilian Rain Forest. Some geographic data was kindly provided by the Institute Brasileiro de Geografia e Estatística. The views and interpretations are the authors' alone and do not necessarily reflect those of any of the supporting organizations.

\section{LITERATURE CITED}

Brandon, K., L. J. Gorenflo, A. S. L. Rodrigues, and R. W. Waller. 2005. Reconciling biodiversity conservation, people, protected areas, and agricultural suitability in Mexico. World Development 33 (9):1403-1418.

Brooks, T. M., R. A. Mittermeier, G. A. B. da Fonseca, J. Gerlach, M. Hoffmann, J. F. Lamoreux, C. G. Mittermeier, J. D. Pilgrim, and A. S. L. Rodrigues. 2006. Global biodiversity conservation priorities. Science 313:58-61.

Chomitz, K. M. 2004. Transferable development rights and forest protection: an exploratory analysis. International Regional Science Review 27 (3):348-373.

Chomitz, K. M, and D. Gray. 1996. Roads, land use, and deforestation: a spatial model applied to Belize. World Bank Economic Review 10:487-512.

Chomitz, K. M., K. Alger, T. S. Thomas, H. Orlando, and P. Vila Nova. 2005. Opportunity costs of conservation in a biodiversity hotspot: the case of southern Bahia. Environment and 
Development Economics 10:293-312.

Chomitz, K. M., E. Brenes, and L. Constantino. 1999. Financing environmental services: the Costa Rican experience and its implications. Science of the Total Environment 240:157-169.

Cincotta, R. P., J. Wisnewski, and R. Engelman. 2000. Human population in the biodiversity hotspots. Nature 404:990-992.

Cowling, R. M., and R. L. Pressey. 2003. Introduction to systematic conservation planning in the Cape Floristic Region. Biological Conservation 112(1-2):1-13.

Cowling, R. M., R. L. Pressey, M. Rouget, and A. T. Lombard. 2003. A conservation plan for a global biodiversity hotspot - the Cape Floristic Region, South Africa. Biological Conservation 112 (1-2):191-216.

Faith, D. P., H. A. Nix., C. R. Margules, M. F. Hutchinson., P. A. Walker, J. West, J. L. Stein, J. L. Kesteven, A. Allison, and G. Natera. 2001. The BioRap biodiversity assessment and planning study for Papua New Guinea. Pacific Conservation Biology 6:279-288.

Faith, D.P., G. Carter, G. Cassis, S. Ferrier, and L. Wilkie. 2003. Complementarity, biodiversity viability analysis, and policy-based algorithms for conservation. Environmental Science and Policy 6:311-328.

Ferraro, P. J. 2000. Global habitat protection: limitations of development interventions and a role for conservation performance payments. Conservation Biology 15:990-1000.

Ferraro, P. J., and A. Kiss. 2002. Direct payments to conserve biodiversity. Science 298:1718-1719.

FWI/GFW.2002. The state of the forest: Indonesia. Forest Watch Indonesia and Global Forest Watch, Bogor, Indonesia.

Galindo-Leal, C., and I. de Gusmão Câmara. 2003. Pages 3-11 in C. Galindo-Leal and I. de Gusmão Câmara, The Atlantic Forest of South America: biodiversity status, threats, and outlook. Island Press, Washington, D.C., USA.

Gardner, R. H., B. T. Milne, M. G. Turner, and
R. V. O'Neill. 1987. Neutral models for the analysis of broad-scale landscape patterns. Landscape Ecology 1:5-18.

Gouvêa, J. B. S., L. A. Mattos Silva, and M. Hori. 1976. Fitogeografia. Pages 1-7 in Diagnóstico socioeconômico da região Cacaueira, Volume 7: recursos florestais. Comissão Executiva do Plano da Lavoura Cacaueira and Instituto Interamericano de Ciências Agrícolas (OEA). Ilhéus, Bahia, Brasil.

Guevara, S., and J. Laborde. 1993. Monitoring seed dispersal at isolated standing trees in tropical pastures: consequences for local species availability. Vegetatio 107/108:319-338.

Hoare, A. E. 2006. Divided forests: towards fairer zoning of forest lands. Rainforest Foundation, UK.

Innes, R., S. Polasky, and J. Tschirhart. 1998. Takings, compensation, and endangered species protection on private lands. Journal of Economic Perspectives 12(3):35-52.

Johnston, R., and M. Madison. 1997. From landmarks to landscapes: a review of current practices in the transfer of development rights. Journal of the American Planning Association 63:365-78.

Landau, E. C., A. Hirsch, and J. Musinsky. 2003. Cobertura Vegetal e Uso do Solo do Sul da Bahia Brasil, scale 1:100.000, 1996-97. Map in digital format. In P. I. Prado, E. C. Landau, R. T. Moura, L. P. S. Pinto, G. A. B. Fonseca, and K. Alger, editors. Corredor de Biodiversidade da Mata Atlântica do Sul da Bahia. (CD-ROM) Ilhéus, Brazil, IESB/CI/CABS/UFMG/UNICAMP.

Landau, E. C. 2001. Thesis. Universidade Federal de Minas Gerais, Belo Horizonte, Brazil.

Mahar, D. J. 2000. Agro-ecological zoning in Rondônia, Brazil: what are the lessons. Pages 115-128 in A. Hall, editor. Amazonia at the crossroads: the challenge of sustainable development. Institute of Latin American Studies, University of London, London, UK.

Margules, C. R., and R. L. Pressey. 2000. Systematic conservation planning. Nature 405:243-253.

Martini, A. M. Z., J. G. Jardim, and F. A. M. dos Santos. In press. Floristic composition and growth 
habits of plants in understory, natural treefall gaps, and fire-disturbed areas of a tropical forest in southern Bahia, Brazil. In W. W. Thomas, editor. The Atlantic Coastal Forests of northeastern Brazil. Memoirs of the New York Botanical Garden, Bronx, New York, USA.

Mendelsohn, R., W. Nordhaus, and D. Shaw. 1994. The impact of global warming on agriculture: a Ricardian analysis. American Economic Review 84(4):753-771.

Myers, N., R. A. Mittermeier, C. Mittermeier, G. A. B. da Fonseca, and J. Kent. 2000. Biodiversity hotspots for conservation priorities. Science 403:853-858.

Paglia, A. P. 2003. Análises de viabilidade populacional: quantos indivíduos? Serão eles suficientes? Estudo de caso para espécies ameaçadas da mata atlântica do sul da Bahia. In P. I. Prado, E. C. Landau., R. T. Moura, L. P. S. Pinto, G. A. B. Fonseca, and K. Alger, editors. Corredores de Biodiversidade na Mata Atlântica do Sul da Bahia. (CD-ROM), IESB/CI/CABS/UFMG/UNICAMP, Ilhéus, Bahia, Brazil.

Parkhurst, G. M., J. F. Shogren, C. Bastian, P. Kivi, J. Donner, and R. B. W. Smith. 2002. Agglomeration bonus: an incentive mechanism to reunite fragmented habitat for biodiversity conservation. Ecological Economics 41: 305-328.

Prado P. I., L. P. Pinto, R. T. Moura, and E.C. Landau. 2003. Avaliação de modelos de distribuição geográfica e sua aplicação para prever a ocorrência de espécies de mamíferos no Corredor Central da Mata Atlântica. In P. I. Prado, E. C. Landau., R. T. Moura, L. P. S. Pinto, G. A. B. Fonseca, and K. Alger, editors. Corredores de Biodiversidade na Mata Atlântica do Sul da Bahia (CD-ROM), IESB/CI/CABS/UFMG/UNICAMP, Ilhéus, Bahia, Brazil.

Ricketts, T. H., E. Dinerstein, T. Boucher, T. M. Brooks, S. H. M. Butchart, M. Hoffmann, J. F. Lamoreux, J. Morrison, M. Parr, J. D. Pilgrim, A. S. L. Rodrigues, W. Sechrest, G. E. Wallace, K. Berlin, J. Bielby, N. D. Burgess, D. R. Church, N. Cox, D. Knox, C. Loucks, G. W. Luck, L. L. Master, R. Moore, R. Naidoo, R. Ridgely, G. E. Schatz, G. Shire, H. Strand, W. Wettengel, and E. Wikramanayake. 2005. Pinpointing and preventing imminent extinctions. Proceedings of the National Academy of Sciences of the United States of America 102:18497-18501.

Rodrigues, A. S. L., S. J. Andelman, M. I. Bakarr, L. Boitani, T. M. Brooks, R. M. Cowling, L. D. C. Fishpool, G. A. B. da Fonseca, K. J. Gaston, M. Hoffmann, J. S. Long, P. A. Marquet, J. D. Pilgrim, R. L. Pressey, J. Schipper, W. Sechrest, S. N. Stuart, L. G. Underhill, R. W. Waller, M. E. J. Watts, and X. Yan. 2004. Effectiveness of the global protected area network in representing species diversity. Nature 428(6983):640-643.

Rolim, S., and A. Chiarello. 2004. Slow death of Atlantic Forest trees in cocoa agroforestry in southeastern Brazil. Biodiversity and Conservation 13:2679-2694.

Rosenzweig, M. L. 2003. Win-win ecology: how the Earth's species can survive in the midst of human enterprise. Oxford University Press, New York, New York, USA.

Saatchi, S., D. Agosti, K. Alger, J. Delabie, and J. Musinsky. 2001. Examining fragmentation and loss of primary forest in the southern Bahian Atlantic forest of Brazil with radar imagery. Conservation Biology 15(4):867-875.

Salzman, J., B. H. Thompson, Jr., and G. C. Daily. 2001. Protecting ecosystem services: science, economics, and policy. Stanford Environmental Law Journal 20(2):309-337.

Sanderson, J., and L. D. Harris, editors. 2000. Landscape ecology: a top-down approach. Lewis, Washington, D.C., USA.

Sanderson, J., K. Alger, G. A. B. da Fonseca, C. Galindo-Leal, V. H. Inchausty, and K. Morrison. 2003. Biodiversity conservation corridors: considerations for planning, implementation and monitoring of sustainable landscapes. Conservation International, Washington, D.C., USA.

Santos, P. S. 2005. Técnicas de sensoriamento remoto voltadas á análise espaço-demporal da cobertura vegetal na região extremo sul da Bahia, Brasil. Technical Report prepared for Associação Flora Brasil. Itamaraju, Brasil.

Smith, R. 1995. The conservation reserve program as a least-cost land retirement mechanism. American Journal of Agricultural Economics 
77:93-105.

Smith, R. B. W., and J. F. Shogren. 2002. Voluntary incentive design for endangered species protection. Journal of Environmental Economics and Management 43:169-187.

Stoms, D., K. M. Chomitz, and F. W. Davis. 2004. TAMARIN: a landscape framework for evaluating economic incentives for rainforest restoration. Landscape and Urban Planning 68(1):95-108.

Stoneham, G., V. Chaudri, A. Ha, and L. Strappazon. 2003. Auctions for conservation contracts: an empirical examination of Victoria's BushTender trial. Australian Journal of Agricultural and Resource Economics 47(4):477-500.

Thomas, W. W., A. M. de Carvalho, A. M. Amorim, J. Garrison, and A. L. Arbeláez. 1998. Plant endemism in two forests in southern Bahia, Brazil. Biodiversity Conservation 7(3):311-322.

Thomas, W. W., and M. R. V. Barbosa. In press. Natural Vegetation Types in the Coastal Forest Zone of Northeastern Brazil. In W.W.Thomas, editor. The Atlantic Coastal Forests of Northeastern Brazil. Memoirs of the New York Botanical Garden.

Uchida, E., J. Xu, and S. Rozelle. 2005. Grain for Green: Cost-Effectiveness and Sustainability of China's Conservation Set-Aside Program. Land Economics 81(2): 247-264.

Veloso, H. P. 1992. Sistema Fitogeográfico. Pages 9-38 in Fundação Instituto Brasileiro de Geografia e Estatística (IBGE) Manual Técnico da Vegetação Brasileira. IBGE, Rio de Janeiro.

World Bank. 2003. Implementation completion report CPL-34440 on a loan in the amount of US\$167.0 million to the Federative Republic of Brazil for a Rondonia Natural Resources Management Project. Report Number 26080. World Bank, Washington, D.C., USA. 
APPENDIX 1. Additional methodological information

\section{Definition of the Environmental Benefits Index}

The term Environmental Benefits Index (EBI) was inspired by the USDA Conservation Reserve Program as a programmatic rule for ranking the cost-effectiveness of land units bidding for program participation. The scoring procedure uses an arbitrary but plausible and simple-to-implement point system. The highest points are assigned to mature forest and to wetlands. Secondary forest and shade cocoa/cabruca are assigned moderate point values if located in the same land unit as mature forest, because they then offer good prospects for forest regeneration. Otherwise secondary forest and shade cocoa/cabruca receive a lower score.

EBI was defined as follows:

$\mathrm{EBI}=[1000 /(\text { per-hectare land value })]^{*}$

$\left[5 * \mathrm{P} \_\right.$mature +

$5 * \mathrm{P} \_$wetland +

$3 * \mathrm{P} \_$cabruca $* \mathrm{D}\left(\mathrm{P} \_\right.$mature $)+$

$3 * \mathrm{P}_{-}$secondary $* \mathrm{D}\left(\mathrm{P} \_\right.$mature $)+$

$1 * \mathrm{P} \_$cabruca $*\left(1-\mathrm{D}\left(\mathrm{P} \_\right.\right.$mature $\left.)\right)+$

$1 * \mathrm{P} \_$secondary $*\left(1-\mathrm{D}\left(\mathrm{P} \_\right.\right.$mature $\left.\left.)\right)\right]$

where $\mathrm{D}(\mathrm{x})=0$ if $\mathrm{x}=0$

$\mathrm{D}(\mathrm{x})=1$ if $\mathrm{x}>0$

P_mature $=$ proportion of planning unit in mature forest

P_cabruca $=$ proportion of planning unit in cabruca and other tree shaded cocoa

P_secondary $=$ proportion of planning unit in secondary forest

where land value and land cover proportions are calculated for the part of a land unit that is not urban, water-covered, or in a protected area.

\section{Land cover transition rules}

Lacking a quantitative, behavioral model for land use change in Bahia, the authors employed a simple deterministic model of change, assuming continuation of current trends over a notional period of two decades. A transition matrix specified future land cover under two different states for the land unit: businessas-usual, and protected status (i.e. under conservation easement). Selection into protection places all vegetation into 'regenerating forest' status. Regeneration is costless (due to assumed seed sources) except for pasture/agriculture pixels that are not in the same land unit as mature or secondary forest; for these areas a reforestation cost is incurred.

In the business-as-usual scenario we assume that, despite legal regulations against clear-cutting or degradation of forest, mature forest will be degraded gradually into secondary forest through timber and firewood extraction and agricultural encroachment. Secondary forest will be permanently converted to pasture or agriculture except in areas where it is near mature forest; in such situations, it will remain secondary forest. In the business-as-usual state, the fate of cabruca and other tree shaded cocoa culture depends on local agronomic conditions. Cabruca will be partly replaced by other forms of agriculture except in areas where previously established on soils with the highest agricultural production capacity (prime 
farmland), on steep terrain (larger than $70 \%$ slope) or on floodplains. For convenience of processing, surviving cabruca and other tree shaded cocoa was reclassified to secondary forest, because we assume that it has the same properties buffering edges and facilitating gap crossing. Pasture and agriculture will remain unchanged, because we assume no spontaneous abandonment and regeneration of farmland. Bare land is assumed to be a temporary state of agricultural land that is reclassified as agriculture/pasture for the future. Urban land uses and other habitat types (e.g., mangrove, wetlands, water bodies) cannot be converted into forest and are assumed to remain in their present condition. Similarly, we did not anticipate changes for restinga and caatinga. For a summary of all rules see the table below.

\begin{tabular}{|c|c|c|}
\hline Land Cover Class & Business As Usual Scenario & Restoration Scenario \\
\hline Mature forest & Secondary forest & Mature forest \\
\hline Secondary forest & $\begin{array}{l}\text { Secondary forest if near mature forest; otherwise } \\
\text { pasture/agriculture }\end{array}$ & Restored forest \\
\hline $\begin{array}{l}\text { Cabruca and other tree shaded } \\
\text { cocoa }\end{array}$ & $\begin{array}{l}\text { Secondary forest on fertile soils, in steep terrain or } \\
\text { on flood plains; otherwise pasture/agriculture (see } \\
\text { text for details) }\end{array}$ & Restored forest \\
\hline Eucalyptus plantation & No change & No change \\
\hline Pasture/agriculture & No change & Restored forest \\
\hline Bare soil & Pasture/ agriculture & Restored forest \\
\hline Restinga & No change & No change \\
\hline Caatinga & No change & No change \\
\hline Mangrove & No change & No change \\
\hline Wetlands & No change & No change \\
\hline Water & No change & No change \\
\hline Urban & No change & No change \\
\hline No data & No change & No change \\
\hline
\end{tabular}

